\title{
Physically and Chemically Evaluation for the Water Quality Criteria in a Farm on Akcay
}

\author{
Ebru Yilmaz ${ }^{1}$, Cengiz Koç ${ }^{2}$ \\ ${ }^{1}$ Bozdogan Vocational School, Adnan Menderes University, Bozdogan, Turkey \\ ${ }^{2}$ Department of Civil Engineering, Engineering Faculty, Bilecik Şeyh Edebali University, Bilecik, Turkey \\ Email: cengizko9@gmail.com
}

Received May 3, 2013; revised June 5, 2013; accepted July 2, 2013

Copyright (C 2014 Ebru Yilmaz, Cengiz Koç et al. This is an open access article distributed under the Creative Commons Attribution License, which permits unrestricted use, distribution, and reproduction in any medium, provided the original work is properly cited. In accordance of the Creative Commons Attribution License all Copyrights (C) 2014 are reserved for SCIRP and the owner of the intellectual property Ebru Yilmaz, Cengiz Koç et al. All Copyright (C) 2014 are guarded by law and by SCIRP as a guardian.

\begin{abstract}
Akcay is a high flow stream supported with strong bracket and is emerging from border of Beyagac County in Denizli province. In this study, it was performed for determining some limnological traits of Akcay River in Bozdogan County in Aydin province. This study was conducted with a 12-month period between January 2010 and December 2010. The chosen pilot farm is raising fish (Oncorhynchus mykiss). The water of Akcay River is used on farm. Some limnological parameters (dissolved oxygen, temperature, pH, EC, nitrite, nitrate, orthophosphate, minerals) were investigated for determining the water quality of zone.
\end{abstract}

\section{KEYWORDS}

Turkey; Akcay; Pollution; Water Quality

\section{Introduction}

Pollution can be described as "the introduction by man into the environment matter or energy sensitive to cause dangers to human health, damage to living facilities and ecological systems, harm to constructions or amenity, or interference with legalise uses of the environment”. Pollutants, as a rule, can be taken up by humans through inhalation, contacting with skin or the consumption of nutrients. The significant environmental pollutants are the heavy metals (e.g. lead, cadmium or mercury), dangerous gases (e.g. sulphur dioxide, carbon monoxide, nitrogen oxide and ozone, nitrous composites) and chlorinated hydrocarbons such as DDT or vinyl chloride. The most general resources of pollutants are industrial or production sites, power stations, aqua culture, agriculture and domestic heating, which release pollutants in the solid, liquid or gaseous forms. The environmental pollutants can cause severe or long-period harm (such as, by way of carcinogenic, mutagenic or embryotoxic matters). Specially, hazardous pollutants are signalized by a good proportion of absorption into the human body (resorption), slow and lengthy biological half-life, and high stability. Thereby, they can remain in the natural circulatory system for a long period and unfold their full harmful impact [1].

Water is the most essential resource of all nutrients required by animals. The water into body is the roleplaying in anabolic and catabolic mechanism. To be taken into body of water shows alteration between species, for example, salt water fishes and freshwater fishes. The amount of ion in bloods of freshwater fishes is richer than amount of ion from their water environment. Therefore, water comes from branchia to body of water freshwater fishes, and so water does not need to like a hole in the head through mouth [2].

The water requirements of fishes are effected by some factors, such as, quality of water source, nutrient composition $(\mathrm{N}, \mathrm{Na}+$ and $\mathrm{K}+\%$ ) and environment factors (air motion and relative humidity) [3].

Water quality parameters of concern are traditionally dissolved oxygen (because it may cause fish kills at low concentrations) as well as phosphates, ammonium and nitrate (because they may cause significant changes in community structure if released into aquatic ecosystems in excessive amounts) [4]. Water pollution is identified as the destruction of natural structure of the water sour- 
ces because of physical or chemical factors [5]. Due to the factors varying and polluting water's configuration and duty, some measurements are created in the speciality and quality of the water. The organisms living in aquatic systems are influenced by these variations. The aim of this study is to evaluate measurements of water quality established on Akcay River and the physical and chemical factors.

\section{Material and Methods}

\subsection{Material}

Akcay is the most important bracket of Grand Menderes River. Akcay River Basin is limited in Dandalas in the East, Cine River Basin in the West and Grand Menderes River in The North. The rain area of Akcay is $3100 \mathrm{~km}^{2}$.

Specific sampling points was established on part of $4.500 \mathrm{~m}^{2}$ of $18.731 \mathrm{~m}^{2}$ field that precondition M20C3D screw plate-parcel 2185 at Gurbet local of Ziyaretli flat in Ziyaretli village in Aydın county. During establishment of farm, it was aimed for seed salmon farming $2,000,000$ pieces/year, salmon farming capacity of 150 tones/year. The seed salmons that were produced in facility were supplied to about $1,040,000$ pieces seed of need of company's capacity of 260 tones/year that belonging to same company in Kemer village in Bozdogan county in Aydin province. It was used 600,000 pieces seed salmons that were raised because of production of portion fish at the same facility. Other seed salmons were sold to fish farm at vicinal provinces (Mugla, Denizli and situated in Aydin).The farming area was found short of 8 $\mathrm{km}$ to Bozdogan county $94 \mathrm{~km}$ to Aydin province. The facility was occupied at a distance $2.7 \mathrm{~km}$ to Ay-
din-Bozdogan road. The main road open to traffic all the year round and it was found at a distance $8 \mathrm{~km}$. The facility does not have any problem in terms of transportation. The power line was found at field of facility. The water provides from Akcay together with other companies. The working area was shown in Figure 1.

\subsection{Methods: Chemical analysis}

Samples were taken in Akçay River in 2010. Samples were collected fish farm by the side of Akçay River.

Samples were taken from with an instrument named Nansen bottle as spot sample in specific sampling points. Nansen bottle was put into intended depths in a regular speed, water was filled inside along a vertical plan, and bottle was closed by the effect of a burden from above. Before the closed bottle which was drove up was filled into transparent bottle, its potential temperature was measured, after that sample was poured into the jars. The temperature, ph, conductivity and dissolved oxygen were measured on the premises. Whereupon, samples were taken to the laboratories by the help of a vehicle as soon as possible and analysis were immediately started.

Mercury thermometer which has $0.1^{\circ} \mathrm{C}$ sensitivity measures the temperature, $\mathrm{ph}$ is measured with $\mathrm{pH}$ meter named Orion (Model SA 720), electricity conductivity is with conductometer named Jenway. In addition to that, nitrite and nitrate is with calorimetric method, dissolved oxygen is with oxygen meter. Orthophosphate is measured with molybdate ascorbic acid method, sodium and potassium is with flame fotometry, calcium and magnesium is with automatic absorption Spectrophotometric equipment named Perkin Emler. Analysis is made according to the international standard methods [6]. The

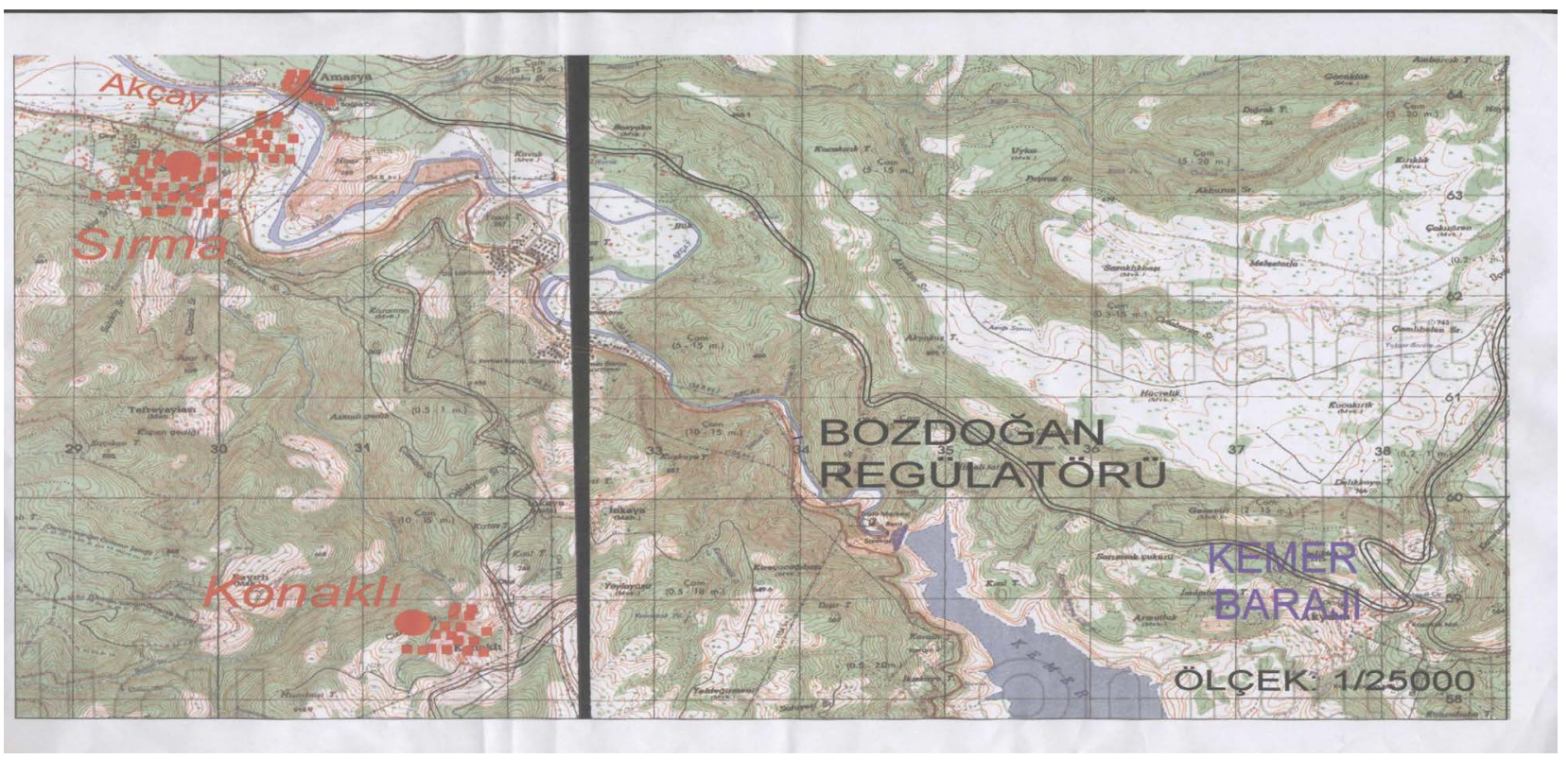

Figure 1. Working area. 
water samples were analyzed both physically and chemically in the Soil and Water Laboratory of the Branch Directorate of Quality Control and Laboratory, Regional Directorate $\mathrm{XXI}^{\mathrm{st}}$ of the State Hydraulic Works.

\section{Results and Discussion}

The quality changes in the Akcay River water content were monitored in seasonal periods. In the results, the physical and chemical characteristics of the river varied seasonally, as shown in (Table 1).

The results of all analysis related to values of water were shown in Table 1 . The values of temperature were changed between $9^{\circ} \mathrm{C}$ and $22^{\circ} \mathrm{C}$ on January to December. The values of $\mathrm{pH}$ were found between 8 and 8.8. The highest value of EC (Electrical conductivity) was taken on December (830) and the lowest value was taken on January (340). The nitrate values were change between 0.008 and 0.1 on January to December. The highest value of nitrite was taken on December (4.3) and the lowest of value was taken on May-June (0). The values of dissolving oxygen were changed 7.2 and 9.9. The highest value of Orthophosphate were taken on December (0.12) and the lowest of value was taken on July-August (0). The sodium values were changed 7.2 and 19.9 between January and December. The highest value of potassium were taken on December (3.3) and the lowest of value was taken on August (1.6). The calcium was taken similar values on April to June, September-October and MarchDecember. Finally, the highest value of magnesium was taken on December, while similar values were taken on April, July and September.

\subsection{Temperature}

Temperature generally changes with depth in the rivers and reservoirs in summer. As a result of this change, stratification can become in the rivers. Temperature is the most important parameter in determining the stratification in the rivers. Temperature affects biological, chemical and physical activities in the water source. Thus, the concentration of many parameters is changes. When the temperature of the water increased, the speed of chemical reactions and vaporization of items increased in the water. The increase in temperature of the water decreases solubility of the gases such as $\mathrm{O}_{2}, \mathrm{CO}_{2}, \mathrm{~N}_{2}$, and $\mathrm{CH}_{4}$. Metabolic rate of aquatic organisms depends on temperature. Increase in the breathe rate of organisms in hot waters rises oxygen consumption and causes the deformation of organic substances. When provisions of feeder are suitable, it is running up bacteria and phytoplankton cause rise in muddiness of the water in a short time. In the study, which aims to determine temperature of the river, minimum temperature is $9^{\circ} \mathrm{C}$ (February), maximum temperature is $22^{\circ} \mathrm{C}$ (August) in 2010.

\section{2. $\mathrm{pH}$}

$\mathrm{pH}$ as defined by Sorenson is negative logarithm of hydrogen ion concentration. At a given temperature the acidic or basic character of a solution is indicated by $\mathrm{pH}$ or hydrogen ion activity [7]. When data taken from the sampling points are analyzed, the minimum $\mathrm{pH}$ value in the river is 8.0 (December) and maximum $\mathrm{pH}$ value is 8.8 (August) in 2010.

\subsection{Electrical Conductivity (EC)}

The amount of EC rises depending on increase in temperature. In this study, maximum EC rate was measured as $830 \mu \mathrm{S} / \mathrm{cm}$ in 2010 December; minimum EC rate was measured as $340 \mu \mathrm{S} / \mathrm{cm}$ in 2010 January. Electrical con-

Table 1. The results of chemical analyses of water samples taken from Akçay River (2010).

\begin{tabular}{|c|c|c|c|c|c|c|c|c|c|c|c|c|}
\hline Months & January & February & March & April & May & June & July & August & September & October & November & December \\
\hline Temperature $\left({ }^{\circ} \mathrm{C}\right)$ & 12 & 9 & 13 & 16 & 18 & 20 & 20 & 22 & 18 & 16 & 14 & 12 \\
\hline pH & 8.1 & 8.4 & 8.3 & 8.4 & 8.6 & 8.7 & 8.7 & 8.8 & 8.6 & 8.4 & 8.1 & 8 \\
\hline $\mathrm{EC}(\boldsymbol{\mu s} / \mathrm{cm})$ & 340 & 345 & 400 & 575 & 600 & 608 & 590 & 582 & 578 & 754 & 765 & 830 \\
\hline $\mathrm{NO}_{2}(\mathrm{mg} / \mathrm{L})$ & 0.033 & 0.035 & 0.05 & 0.1 & 0.006 & 0.008 & 0.011 & 0.013 & 0.014 & 0.015 & 0.008 & 0.004 \\
\hline $\mathrm{NO}_{3}(\mathrm{mg} / \mathrm{L})$ & 1 & 1.2 & 0.6 & 0.5 & 0 & 0 & 0.10 & 0.8 & 1 & 1.8 & 3.2 & 4.3 \\
\hline DO (mg/L) & 9.6 & 9.9 & 8.7 & 7.7 & 7.9 & 9.3 & 8.6 & 7.9 & 7.2 & 7.7 & 8.3 & 8.8 \\
\hline o-PO ${ }_{4}(\mathrm{mg} / \mathrm{L})$ & 0.10 & 0.11 & 0.09 & 0.08 & 0.03 & 0.01 & 0 & 0 & 0.04 & 0.05 & 0.05 & 0.12 \\
\hline $\mathrm{Na}(\mathrm{mg} / \mathrm{L})$ & 11 & 7.2 & 9 & 9.2 & 11 & 12.8 & 10 & 10.52 & 11.8 & 15.96 & 16.7 & 19.9 \\
\hline $\mathbf{K}^{+}(\mathbf{m g} / \mathrm{L})$ & 2.1 & 2.3 & 2.2 & 2.2 & 1.9 & 1.8 & 1.79 & 1.6 & 2.3 & 2.31 & 2.6 & 3.3 \\
\hline $\mathrm{Mg}^{+2}(\mathrm{mg} / \mathrm{L})$ & 38.7 & 26.8 & 34 & 51.1 & 52 & 52.1 & 51,1 & 50 & 51.1 & 59.8 & 63 & 64.4 \\
\hline
\end{tabular}


ductivity is an indicator of the amount of total dissolved substitution in water. Conductivity changes depending on geological structure and rainfall; however, it doesn't become affected by nutrients in the water [8].

\subsection{Nitrite}

The concentration of nitrite in natural water is typically low in the range [9].

Minimum nitrite rate in Akcay river is $0.004 \mathrm{mg} \cdot \mathrm{L}^{-1}$ in December, maximum nitrate rate is $0.1 \mathrm{mg} \cdot \mathrm{L}^{-1}$ in 2010 April. The values of nitrite of Akcay River are not risky for fish.

\subsection{Nitrate}

Natural levels of nitrate in waterbodies are typically lower than $1 \mathrm{mg} \cdot \mathrm{L}^{-1}$. Where nitrite and ammonia are toxic, nitrate is virtually harmless, with direct toxic effects typically not observed until concentrations greater than $1000 \mathrm{mg} \cdot \mathrm{L}^{-1}$ [10]. Maximum nitrate rate in Akcay river is $4.3 \mathrm{mg} \cdot \mathrm{L}^{-1}$ in December, minimum nitrate rate is $0 \mathrm{mg} \cdot \mathrm{L}^{-1}$ in 2010 in June. Actually the amount of nitrate is not high in river, but it is estimated that high nitrate concentrations encourage planktons and aquatic plants to growth, so efficiency of fish can increase. The values of nitrate in Akcay river not risky for fishes.

\subsection{Dissolved Oxygen}

Dissolved oxygen (DO) is one of the most fundamental parameters in water, as it essential to the metabolism of all aerobic aquatic organisms. It is added stream flow aeration, and is consumed from the waterbody by bacterial, plant and animal respiration, decaying plants and organisms, and chemical oxidation [11]. Depending on lack of oxygen, it was claimed that the amount of fish dropping, lactic acid, $\mathrm{Na}, \mathrm{K}^{+}, \mathrm{Mg}^{2+}, \mathrm{Cl}$ and inorganic phosphate increased [12]. Dissolved oxygen concentration shows the degree of contamination of water and organic substance concentration in water. Dissolved oxygen concentrations often are the primary factor limiting rainbow trout production [13]. Effective DO management is essential for high-density aquaculture systems. Oxygen demand varies with fish species, life stage, size, stock health, water quality, feeding regime, and bacterial respiration rate, among other factors $[14,15]$. Rainbow trout typically consume between 100 and $800 \mathrm{mg} \mathrm{O} / \mathrm{kg}$ body mass/h and DO consumption often peaks after feeding. Oxygen solubility is dynamic and depends primarily upon temperature, salinity, dissolved gas composition, and atmospheric pressure [16,17].

According to my studies, within the samples taken from Akcay River in 2010, maximum dissolved oxygen concentration rate was measured as $9.9 \mathrm{mg} \cdot \mathrm{L}^{-1}$ at in February and minimum dissolved oxygen concentration rate was measured as $7.2 \mathrm{mg} \cdot \mathrm{L}^{-1}$ in September.

\subsection{Orthophosphate}

Phosphorus is an important mineral in nucleic acids and cellular membranes, the main representative of the structural components of the skeletal tissues, and it is directly involved in energy processes [18]. Levels of phosphate in waterbodies are typically lower than $3 \mathrm{mg} \cdot \mathrm{L}^{-1}$.

According to my own studies, in 2010 April minimum orthophosphate rate was measured as $0 \mathrm{mg} \cdot \mathrm{L}^{-1}$ in Akçay River. The maximum rate was measured as $0.12 \mathrm{mg} \cdot \mathrm{L}^{-1}$ in December.

\subsection{Minerals (Sodium, Calcium, Magnesium, Potasium)}

In 2010 February, minimum sodium rate was measured as $7.2 \mathrm{mg} \cdot \mathrm{L}^{-1}$ within Akçay River. Maximum sodium rate was observed as $19.9 \mathrm{mg} \cdot \mathrm{L}^{-1}$ within Akçay River in December. The natural range of sodium ions in water and soil is so low, their existence can show river pollution caused by human activities. Sodium is combined with chloride quite often. Calcium comes towards water from the soil, industrial wastes and the natural resources. It decreases the poisoned effect of many substances that may be poison for fish living in the water. In the analysis made in 2010, calcium amount was founded $28.1 \mathrm{mg} \cdot \mathrm{L}^{-1}$ within Akcay River in February. Maximum sodium rate was observed as $56.4 \mathrm{mg} \cdot \mathrm{L}^{-1}$ within Akcay River in September.

Magnesium is an essential nutrient required for numerous biochemical and physiological functions. Magnesium is present in variable amounts in common animal feed. In The analysis made in 2010 magnezyum rate was founded $26.8 \mathrm{mg} \cdot \mathrm{L}^{-1}$ within Akcay River in February. Maximum sodium rate was observed as $64.4 \mathrm{mg} \cdot \mathrm{L}^{-1}$ within Akcay River in December. It was pointed out that, there is less than $14 \mathrm{mg} / \mathrm{l}$ magnesium in $95 \%$ of water which has good fish faunas in the USA. Also, it is possible that there is $100 \mathrm{mg} \cdot \mathrm{L}^{-1}-400 \mathrm{mg} \cdot \mathrm{L}^{-1}$ poisoned magnesium in fresh water, however, fresh water fish living in $1000 \mathrm{mg} \cdot \mathrm{L}^{-1}$ magnesium can be available in salty water that include sodium and calcium.

In the analysis made in 2010, potassium amount was founded $1.6 \mathrm{mg} \cdot \mathrm{L}^{-1}$ within Akcay River in August. Maximum potassium rate was observed as $3.3 \mathrm{mg} \cdot \mathrm{L}^{-1}$ within Akçay River in December. It was touched on that potassium is not dangerous for fish until $400 \mathrm{mg} \cdot \mathrm{L}^{-1}$ level.

In this study, it was evaluated quality of river water and was determined analysis of water one year in Akcay River. Besides, it was shown usage as first class water of Akcay River. In this study, it was determined that not risky in point of calcium, magnesium and potassium 
values of water in Akcay river for fishes. The some limnological parameters may have an impact on animal performance (health and productivity).

\section{Conclusions}

When obtained data belonging to physicochemical parameters in this study are evaluated according to water quality standards in Water Pollution Control Regulation, it can be concluded that water of Akcay occupies highquality water class. In Water Pollution Control Regulation, it is announced that water belonging to first class is available for provision of drinking water only with disinfection, rational aims, production of trout, animal production, need of farm and other aims. Considering this situation in Akcay, it can be seen that rainbow trout breeding is done in the areas close to Akcay River.

In recent years, there are many strict rules and regulations applied for environmental concerns and sustainability in many countries about aquaculture. Activities related to aquaculture should be environment friendly as well as economical. This new approach is so important in terms of protecting environmental balance. For this reason, in Akcay which has a good water quality and has no serious pollution problem, it is so necessary to protect fresh water ecosystem and to continue monitoring studies about environmental effects that may arise from rainbow trout farming in more detail for providing sustainable development.

\section{REFERENCES}

[1] M. W. Holdgate, “A Perspective of Environmental Pollution,” Cambridge University Press, Cambridge, 1987, 279 p.

[2] B. J. Wikgren, "Osmotic Regulation in Some Aquatic Animals with Special Reference to the Influence of Temperature,” 1953, $102 \mathrm{p}$.

[3] E. J. Ling, "Water Quality for Virginia Dairies,” 2012. www.vtdairy.dasc.vt.edu/docs/cow-colleges/2012cc/pres24-ling.pdf

[4] P. J. Gerber and H. Steinfeld, "The Global Environmental Consequences of The Livestock Sector's Growth,” Bulletin of The International Dairy Federation, Vol. 443, 2010, pp. 4-12.

[5] C. Copeland, "Animal Waste and Water Quality: EPA Regulation of Concentrated Animal Feeding Operations (CAFOs)," Congressional Research Service, 24 p.

[6] APHA, "Standard Methods for the Examination of Water and Wastewater,” 21st Edition, American Public Health
Association, Washington, 2005.

[7] Anonymous, "Pollution in Eğrekkaya Reservoir and Basin,” Research Report, Ministry of Energy and Natural Resources, General Directorate of State Hydraulic Works, 2001.

[8] M. Temponeras, J. Kristiansen and M. Moustaka-Gouni, "Seasonal Variation in Phytoplankton Composition and Physical-Chemical Features of the Shallow Lake Doirani," Macedonia, Greece,” Hydrobiologia, Vol. 424, No. 1-3, 2000, pp. 109-122.

http://dx.doi.org/10.1023/A:1003909229980

[9] P. Pitter, "Hydrochemistry (in Czech)," Editor VSCHT, Prague, 1999, 568 p.

[10] USEPA, "Ecological Restoration: Linking Restoration Practices to Water Quality Parameters,” Technical Report \# EPA841-F-95-007. United States Environmental Protection Agency, Washington DC, 1995. http://www.epa.gov/OWOW/NPS/Ecology/chap3.html

[11] J. Fripp, P. F. Ziemkiewicz and H. Charkavorki, “Acid Mine Drainage Treatment,” Technical Report \# ERDC TN-EMRRPSR-14, EMRRP Technical Notes Collection, 2000. http://el.erdc.usace.army.mil/elpubs/pdf/sr14.pdf

[12] B. Hossu and Y. Korkut, "Balik Besleme ve Yem Teknolojisi I,” Ege Üniversitesi Su Ürünleri Fakültesi Yayinlari No. 50, Ders Kitabı Dizini No. 19, 1996.

[13] C. A. Caldwell and J. Hinshaw, "Physiological and Haematological Responses in Rainbow Trout Subjected to Supplemental Dissolved Oxygen in Fish Culture,” Aquaculture, Vol. 126, No. 1-2, 1994, pp. 183-193. http://dx.doi.org/10.1016/0044-8486(94)90259-3

[14] S. A. Miller, E. J. Wagner and T. Bosakowski, "Performance and Oxygen Consumption of Rainbow Trout Reared at Two Densities in Raceways with Oxygen Supplementation,” Progressive Fish-Culturist, Vol. 57, No. 3, 1995. 206-212. http://dx.doi.org/10.1577/1548-8640(1995)057<0206:PA OCOR $>2.3 . \mathrm{CO} ; 2$

[15] G. A. Wedemeyer, "Physiology of Fish in İntensive Culture Systems,” Chapman and Hall, New York. 1996. http://dx.doi.org/10.1007/978-1-4615-6011-1

[16] J. Colt and B. Watten, "Applications of Pure Oxygen in Fish Culture,” Aquacultural Engineering, Vol. 7, No. 6, 1988, pp. 397-441. http://dx.doi.org/10.1016/0144-8609(88)90003-9

[17] J. A. Hargreaves and C. S. Tucker, "Measuring Dissolved Oxygen Concentration in Aquaculture," Publication \# 4601, Southern Regional Aquaculture Center, Mississipppi State University, Starkville, 2002.

[18] National Research Council (NRC) "Nutrients Requirements of Fish,” National Academy Press, Washington DC, 1993, $114 \mathrm{p}$. 